\title{
En ny kosmopolitisk patriotisme
}

\section{Bjarke Møller}

\section{Det kosmopolitiske demokrati kan blive real- politik, når det går op for europæerne, at natio- nalismens territoriale tænkning igen og igen ender i afmægtighed og hjælpeløshed over for de globale udfordringer}

"Det er et chok for den samlede menneskehed, at vi er trådt ind $i$ en globaliseret verden, hvor de gamle nationale grenser er brudt sammen. Folk ser den gamle verden gå under, og nogle ønsker den gamle orden genindsat."

(Sociologiprofessor Ulrich Beck i interview til Politiken)

Skal man dømme ud fra antallet af solgte nationaltrøjer under årets fodbold-VM, er det svært at påstå, at nationalfølelsen og dens ideologiske overbygning, nationalismen, er gået af mode. Fra Tyskland til Italien til Spanien og England. Nationen er blevet et mode-brand, der sætter sit mærkbare præg på tøjbutikker og fodboldstadions verden over. $\mathrm{Og}$ ambitiøse regeringer fra land til land drømmer om at lave globale 'branding'kampagner, der skal trække turister og virksomheder til fra hele verden.

Det sker på et tidspunkt af historien, hvor den nationale suverænitet og nation-staten i mange henseender ellers fremtræder som det, Ulrich Beck, har kaldt for 'zoombie-kategorier' (Power in the Global Age, 2005)

Globaliseringen af økonomien og liberaliseringen af finansmarkederne har indskrænket de enkelte staters råderum på afgørende strækninger. Mobilitet er blevet hverdag ikke bare for virksomheder og kapital, men også for turister og migranter. Selv de højere uddannelser europæiseres og reformeres for at åbne op for øget mobilitet og konkurrence. Kommunikationen er 
grænseløs og ukontrollérbar på det eksplosivt voksende internet og i 'blogosfæren'.

Folk er på tværs af nationaliteter fælles om at se fodbold-VM, følge multinationale fodboldhold i Champions League og stemme ved det europæiske Melodi Grand Prix. Oveni i de personlige, sociale, lokale, regionale og nationale erfaringer lægges nye lag af europæiske og globale erfaringsrum.

Man skal være mere end almindeligt naiv, hvis man tror, at folks personlige biografi er - og kun kan være - rodfæstet et sted, i et homogent nationalt rum. Mediernes 24 timers billedstrøm beretter konstant om konflikter, krige og alverdens kulturer, så hele verden er ved at blive til globaliseret indenrigspolitik. Viden om fælles og grænseoverskridende miljøproblemer eller frygt for nye sikkerhedstrusler fra ikke-statslige terrornetværker og transnationale kriminelle netværker sætter nationale dagsordener, der dybest set er globale også.

Fronterne mellem det ydre og det indre, mellem indenrigspolitik og udenrigspolitik, opløses og sættes igen og igen til forhandling. Ikke kun i højtidelige multilaterale forhandlinger mellem staterne, men også i de enkelte borgeres hverdag, der bliver stadig mere globaliseret på supermarkedets hylder, i kulturlivet og i de nye madvaner. Globaliseringen er en refleksiv og dynamisk proces i hastighed, dybde og intensi- tet, der ikke er til at ignorere, uanset hvor man kigger hen. Den slår igennem i det lokale liv og dens nye hybride form er, hvad sociologen Roland Robertson har kaldt for 'glokaliseringen'. Globaliseringen tager også retslig form i de universelle menneskerettigheder, når de håndhæves og ikke krænkes.

\section{Gentagelse eller nybrud}

Globaliseringen er bestemt et meget omdiskuteret begreb. Nogle skeptikere har benægtet, at globaliseringen i det 21. århundrede skulle være væsensforskellig fra den gyldne epoke af liberaliseringer og internationalisering først i det 20 . århundrede, der fik en tragisk afslutning med Første Verdenskrig. Andre med hang til historiens brede penselsstrøg mener, at den blot er en ny udgave af historiens svundne imperiale epoker.

Kommunitarister og overbeviste nationalister har malet ideologiske skræmmebilleder af globaliseringen, som noget der er en McDonaldiseret trussel mod de nære, autentistiske, legitime og identitetsskabende fællesskaber. De har groft forsimplet globaliseringen, der som bl.a. sociologen John Urry har påpeget (Global Complexity, 2003), er en meget mere kompleks, tvetydig og åben proces, der skaber nye netværker og interaktioner.

Nogle nyliberale hyperglobalister - som bl.a. japaneren Kenichi Ohmae - har kigget på globaliserin- 
gen med snævre økonomiske briller, og deres prognoser om nationalstatens afslutning har omvendt bestyrket kommunitaristerne og nationalisterne $i$, at globaliseringen og alle dens udtryk - og ikke mindst migranterne - er noget, som staten må beskytte borgerne imod.

Debatten er alt for ofte endt i ideologiske blindgyder, hvor såvel højreorienterede nationalister som venstreorienterede fællesskabsromantikere har fundet hinanden i et fælles forsvar for det gammelkendte. For nationalstaten, imod Den Europæiske Union. For de nationale grænsers genrejsning, imod indvandrerne fra Polen, Afrika og muslimske lande. De allermest inkarnerede nationalister, som bl.a. Søren Krarup fra Dansk Folkeparti, har endda indledt et ideologisk korstog mod de universelle menneskerettigheder, som han betragter som en farlig abstraktion væk fra den nationale ret. Som om legitimiteten kun kan knæsættes nationalt.

I Danmark har Dansk Folkeparti gjort sig til fanebærer for en danskheds-kulturalisme, hvor det at være dansk og bærer af dansk kultur fremhæves og dyrkes på bekostning af alt ikke-dansk, der uddefineres, skoses og foragtes som det og de fremmede. Danskheds-kulturalismen har i det sidste årti præget den bredere offentlighed og er delvist indoptaget af toneangivende politiske partier, så det næsten er blevet tabu at anfægte den (internationalt set) meget hårde danske udlændingepolitik.

National-kulturalismen er ikke et isoleret dansk fænomen. Det en international modbølge at afgrænse sig over for de ikke-nationale. Haiderismen i Østrig og LePenismen i Frankrig er tydelige eksempler på det. I Norge har det indvandrerfjendske Fremskrittsparti endda overhalet Arbejderpartiet i meningsmålingerne. Det er ikke mere bare populistiske og indvandrerfjendske højrefløjspartier, der dyrker nationalismen. Selv socialdemokratiske partier er i de sidste år åbenlyst begyndt at flirte med nationalismen på ny.

Det kan dels være i desperation over det europæiske tomrum, der er opstået på grund af EU's dybe beslutningskrise, og det kan dels være et udtryk for den fremmedfrygt, som gamle arbejdervælgere er blevet grebet af. Det kan også være et forsøg på at hente stemmer på den stigende folkelige skepsis over for globaliseringen af økonomien, og lønmodtageres frygt for outsourcing og tab af job.

I Holland har socialdemokraten Wouter Bos relanceret sit arbejderparti ved bl.a. at kræve en strammere indvandrerpolitik og gå til angreb på multikulturalismen. I Frankrig taler socialisterne lige så meget om $\varnothing$ konomisk patriotisme som de borgerlige partier. Hele 72 procent af franskmændene mener, at globaliseringen truer deres job og virksomheder, og intet tyder på, at de politi- 
ske ledere gør et reelt forsøg på at oplyse borgerne om, at Frankrig faktisk er et af de lande, der økonomisk vinder på globaliseringen og den voksende arbejdsdeling.

I Storbritannien flirter ledende Labour-folk med ideen om at lancere en såkaldt 'progressiv' nationalisme. Tænketanken Demos udgav her i forsommeren et stort essay - skrevet af redaktøren for Prospect, David Goodhart - der opfordrer det britiske Labour-parti til at stille sig i spidsen for et nyt nationalistisk projekt, der skal give borgerne en fælles identitet. "Uden en inklusiv national fortælling, er der fare for balkanisering," advarer Goodhart.

\section{Den destruktive nationalisme}

Det virker unægteligt som den omvendte verden. Var det ikke netop nationalismen og det dertil knyttede had til naboernes nationaliteter og etnicitet, der gjorde Balkan-krigene i 1990'erne så blodige og tragiske?

I det 20. århundrede har nationalismen igen og igen været en destruktiv kraft, der har fået folk til at gå i krig for den abstrakte ideologis fuldbyrdelse - og ikke for menneskenes fredelige samliv og fællesskab. Er nationalismen ikke netop en farlig opskrift på fremtidens krige?

David Goodhart tror, at det er muligt at undgå en gentagelse af den historie. Progressiv nationalisme skal ikke bygge på etnicitet og en mono-kulturel standardrecept, men tværtimod på et aktivt medborgerskab, hvor folk indgår medborgerkontrakter om rettigheder og pligter i en nation med stærke fælles institutioner og en veludviklet velfærdsstat. Det lyder næsten forsonende.

Goodhart har en pointe i den forstand, at mange socialdemokratiske kernevælgere stadig søger en fælles identitet og solidaritetsfølelse, der kan give deres liv en mening over for den benhårde individualisme, den økonomiske kappestrid og de komplekse samfundsforandringer, som presser sig på. Mange af dem vil sikkert stille sig tilfredse, hvis de politiske ledere uden vaklen ville forsvare velfærdsstaten og den sociale sikkerhed.

Men Goodhart vil gå et skridt videre og have genskabt det nationale føleri. Den opgave er vanskelig i Storbritannien, der af historiske årsager er sammensat af flere nationaliteter, og i de sidste årtiers globaliseringsbølger også har taget imod nye generationer af indvandrere. Goodhart vil have Union Jack på gaderne, og fejre 'britiskheden' på en britisk frihedsdag - men han kombinerer sit projekt med et angreb på multikulturalismen og udtalt frygt for at fremmede kulturer kan underminere Storbritanniens sociale sammenhængskraft.

Den såkaldt progressive patriotisme er dermed ved at kamme over i nationalisme og kulturalisme, der er tømt for den liberalisme, pluralisme 
og frihedstænkning, som historisk set har stået stærkt i den amerikanske tradition.

Goodharts tanker virker meget beslægtet med det nations-projekt, som professor ved London School of Economics, Anthony D. Smith, for elleve år siden gjorde sig til talsmand for i bogen Nations and Nationalism in a Global Era. Smith hævdede, at nationalismen er "den eneste realistiske socio-kulturelle ramme for en moderne verdensorden" $\mathrm{i}$ fremtiden og, at den er "politisk nødvendig", fordi "den nationale identitet er socialt funktionel, og nationen er historisk rodfæstet."

Der eksisterer mere end seks tusind forskellige sprog i verden, men langt fra alle nationer er blevet til stater også. Mange samfund definerer sig slet ikke som nationer, endsige italesætter sig som nationalstater. I realiteten er de allerfleste af verdens ca. tohundrede suveræne stater multietniske og flersprogede. $\mathrm{Og}$ det er i sig selv en fascinerende historie. Antallet af nationalstater er tredoblet efter afkoloniseringen af de gamle europæiske imperier i anden halvdel af det 20. århundrede, men det er kun en tiendedel af verdens anerkendte stater, der - som $\mathrm{fx}$ Danmark - har kunnet defineres som 'homogene' nationalstater med et fælles sprog og en forestilling om stadig at besidde en national kultur.

De seneste års migrationer, folkevandringer og ikke mindst globaliseringen af den kulturelle produktion har dog bidraget til at undergrave selve forestillingen om national homogenitet. Alt er blevet mere åbent og flertydigt. Man må i dag seriøst spørge, om det overhovedet giver mening at tale om moderne nationalstater mere. Politiske projekter, der længes efter at rekonstruere det autentiske og homogene nationsfolk og den ægte nations-kultur lukker af for de mange nye muligheder, som globaliseringen økonomisk, kulturelt og ikke mindst politisk åbner op for. Og de benægter den sociale og flerkulturelle virkelighed, som det enkelte stats-samfund godt kan rumme.

\section{Spanien som eksempel}

Alle nationalstater er, som bl.a. historikeren Eric Hobsbawm har påpeget, produkter af en historiskkulturel mytedannelse, der for alvor tog fart med uddannelsesreformer, militær mobilisering og opbygningen af et fælles nationalt sprog i det 19. århundrede. Staten, folket og sproget eksisterede hver især forinden, men det var først i det 18 . og det 19. århundrede, at den moderne nationalstat bliver til ideologisk projekt efter formlen: nation=stat= folk.

I det sene 20. århundrede blev en stribe nye nation-stater født efter sammenbruddet af det sovjetiske imperium - ikke bare Sovjetunionens opløsning, men også opløsningen af dets indflydelsessfære i kølvandet på Berlin-murens fald og helt til de blo- 
dige etnisk-nationale Balkan-krige og delingen af Eksjugoslavien. Den seneste efterdønning var Montenegros folkeafstemning i år, hvor flertallet af befolkningen besluttede at rive sig løs af Serbien.

Selv her i det 21. århundrede er der folk og nationalistiske partier, der stræber efter at gøre projektet til virkelighed. I Vesteuropa er der mikronationalister i regionerne, der drømmer om at rive sig halvt og helt fri af de gamle centralstater. Der er skotter, flamlændere, vallonere, lombardere, galicere, baskere og katalanere, der deler den drøm. Globaliseringen, europæiseringen og moderniseringen af samfundslivet har med deres bølgeslag skabt modbevægelser, hvor nationalisterne lokker med deres identitetspolitik og fortællinger om kulturel samhørighed. Det er også en kamp om magt.

Nationsbyggeprojekter er ikke bare født af myter og arketypiske længsler. De er i høj grad også udtryk for målbevidst magtpolitik. Det ser man i disse år med al tydelighed i Baskerlandet og Katalonien, der på hver deres måde udfordrer den spanske centralstat og grundlaget for Spaniens demokratiske forfatning fra 1978.

Den baskiske terrororganisation, ETA, har myrdet over 850 personer, såret tusinder og terroriseret lokalbefolkningen for at få løsrevet Baskerlandet fra Spanien og dannet et nyt Euskal Herria, der strækker sig ind over den franske grænse og na- boregionen Navarra. Disse ekspansive territoriale krav og krav om at danne en sprogetnisk nation for baskisk-talende har ETA ikke blødt op på, selv om flertallet af borgerne i de områder slet ikke er baskisk-talende og ikke kræver selvstændighed.

Den spanske regering - anført af socialisten José Luis Rodríguez Zapatero - er denne sommer gået til forhandlingsbordet med ETA i et håb om at finde en såkaldt fredsløsning for Baskerlandet, men der er mange politiske forhindringer på vejen. Zapatero håber, at han kan overtale baskerne til at vælge en katalansk vej og acceptere en udvidet selvstyreaftale inden for rammerne af den spanske stat. Vil det være nok?

Ifølge en ny selvstyreaftale er Katalonien defineret som en nation med eget sprog, nationalhymne, nationalflag, eget retsvæsen, egen skatteopkrævning, bilaterale aftaler med den spanske stat og suveræn uddannelsespolitik. I Europa, hvor mønten, militæret og mange markedsreguleringer allerede er EU-anliggender, har katalanerne fået noget, der kan ligne en semi-suverænitet. Selvstyreaftalen blev godkendt ved en katalansk folkeafstemning i juni, hvor tre ud af fire afgivne stemmer sagde ja. Det var et betinget ja.

"Katalonien er stærkt, når folket frit udtrykker sin vilje. (..) Vi føler Katalonien som en nation (..) Vi katalanere kan skrive vores egen histo- 
rie. Ved at tænke på morgendagen,” sagde en passioneret katalansk regeringschef, Pasqual Maragall. Men afstemningen endte som lidt af en parodi på demokrati, for under 50 procent af vælgerne gad stemme, og den nye statut har dermed mindre folkelig opbakning end den selvstyre-statut fra 1979, som den erstatter.

De baskiske nationalister og separatister vil dog ikke nøjes med den katalanske model. De har åbent sagt, at de hellere vil følge Montenegros eksempel. De har store politiske ambitioner, men den historiske parallel holder ikke. Baskerlandet har i modsætning til Montenegro aldrig været en selvstændig stat, og i modsætning til baskerne havde montenegrinerne - efter opløsningskrigen i eks-Jugoslavien fået en forfatningsmæssig ret til at holde folkeafstemning. Den spanske forfatning - der taler om Spaniens uopløselige enhed - har ikke en artikel, der svarer til artikel 60 i den serbiske montenegrinske forfatning fra 2002, der giver begge republikker ret til ved folkeafstemning at ændre deres statutter.

\section{Sproglig udrensning}

Uanset om baskerne og katalanerne får formel politisk selvstændighed, skal man ikke banalisere konsekvenserne af den nationale magtpolitik. I Katalonien og Baskerlandet har de regerende nationalister - med skiftende støtte fra separatister og socialister $-\mathrm{i}$ årevis ført en aggressiv poli- tik for såkaldt sprog-normalisering, så børnene i skolerne kun undervises på henholdsvis katalansk og euskera.

Det har man gjort, selv om et flertal af de respektive regioners borgere har spansk som modersmål og med henvisning til den spanske forfatning i princippet kunne hævde retten til at få spanskundervisning. Men der er tale om et bevidst ideologisk program for sproglig udrensning i skolerne, der også er ved at blive indført på katalanske universiteter, der skal nationalisere nye generationer af borgere, så de ikke føler sig som spanske.

Hverken Katalonien eller Baskerlandet har en forhistorie som suveræne nationalstater. I århundreder har katalanerne og baskerne været en del af Spanien, men nu søger de regionale eliter aktivt at skrive historiebøgerne om, så de fælles historiske bånd til Spanien skrives ud af bøgerne, og den lokale og regionale historie gøres til en oldgammel nationsfortælling. Eller som man kan læse i en baskisk skolebog: "Vi euskaldunes (baskisktalende, red.) har en rig, tiltrækkende og smuk historie. Vi er et kulturelt fællesskab, som ifølge arkæologien, genetikken og lingvistikken har bestået i 30.000 år frem til i dag."

Den form for etnisk og genetisk defineret artsnationalisme er bestemt ikke et teselskab for demokrater. I stedet for at være inklusiv, frigørende og fællesskabs-skabende, vil 
de nationalistiske historieskrivere og de politiske magthavere bruge det som en platform for at udgrænse ikke-baskerne: det vil sige de baskiske, der har en plural identitet, som også er spansk-sproget, europæisk og måske endda omfavner den globale hybridkultur.

Nationalismen forsøger at forsimple et samfund, der er blevet mere komplekst og sammensat. I Baskerlandet søger de aktivt, med sproget som murbrækker, at udgrænse borgere, der føler sig som ikke-nationalister og på en og samme tid føler en spansk og baskisk identitet. Det er et reaktionært projekt, bag hvilket man stadig kan ane nationalistpartiets grundlægger, Sabino Arana, og hans racisme.

Men forestillingen om, at katalanerne er meget mere civiliserede end baskerne, er ved at bryde sammen i disse år. Når myndighederne af hensyn til et nationalt 'normaliseringsprojekt' nægter skolebørn at blive undervist og eksamineret på deres modersmål, og når myndighederne udsteder sprogbøder til forretningsdrivende for kun at reklamere på forfatningens sprog spansk - er nations-tænkningen ved at forvandle sig fra frigørelse til tyranni. Det overraskende er, at det spanske socialistparti - i det strategiske spil om centralmagten i Madrid - ikke tør sige fra over for sprognationalismen i Katalonien og Baskerlandet, men tværtimod støtter den aktivt og stadig mere udtalt fører kampagne for en mere nationalistisk politik i disse regioner. I det spil kan Spaniens fremtid som en samlet nation-stat meget vel blive sat over styr.

Det er ikke bare en debat, der angår Spanien. Den Europæiske Union, der stadig i første række er et samarbejde mellem stater, påvirkes dybt af de centrifugale kræfter, og i processen ændres også forestillinger om, hvad det europæiske projekt kan udvikle sig til i fremtiden. Nationalisterne søger at skabe tætvævede nationale fællesskaber og styrke den sociale samhørighed. Men deres besættelse af at uddefinere de andre, de fremmede og alle dem, der ikke er som dem selv, er også en trussel mod samhørigheden. En opskrift på fremtidige konflikter i hjertet af Europa.

\section{Globaliseringens skæbnefællesskab}

Professor ved London School of Economics David Held har sagt det på den måde, at "selve ideen om, at vi igen skal handle som et forenet folk, der ekskluderer alt og alle dem, der kommer udefra, er uønskelig, uklog og umoralsk."

Hvis moderate politiske partier, som bl.a. de socialdemokratiske partier, flirter med nationalismen i en forestilling om, at de kan gøre den progressiv, kan de ifølge Held "spille kortene over i hænderne på mere yderligtgående nationalister. Nationalismen kan forene indadtil, men den kan også ekskludere folk sprog- 
ligt, etnisk og kulturelt og ekskludere indvandrerne. Jeg foretrækker, at man i stedet genopfinder det politiske projekt ved at formulere fælles værdier, der binder folk sammen og giver dem en identitet, der rækker ud over nationen."

David Held har skrevet en række bøger om globaliseringen (bl.a. bogen Global Transformations, 1999). Han har overbevisende argumenteret for, at globaliseringen politisk, $ø$ konomisk og kulturelt er ved at skabe en række overlappende skæbnefællesskaber, hvor de enkelte landes skæbne og handlerum i stigende grad bliver vævet sammen.

Men selv om han mener, at globaliseringen i intensitet, ekstensitet og hastighed er ved at 'transformere' det klassiske suverænitetsbegreb og rejse nye globale politiske udfordringer, er han omvendt ikke af den opfattelse, at nation-staten er ved at blive skrevet ud af verdenshistorien.

For ham at se er nation-staten stadig en central demokratisk enhed. Men da nationalstaten ikke er i stand til på egen hånd at løse alle de nye udfordringer, den står overfor med stigende migration, klimaproblemer og globaliseringen, har han slået til lyd for, at der udvikles en ny form for global politik og reguleringer.

Nation-staten vil stadig spille en rolle, men den må indlejres i en multilateral retsorden og en global, social og demokratisk politik. Kontinentale og overnationale samar- bejdsforaer som EU må føres videre, så de med tiden også kan brede sig på det globale niveau. Held anbefaler en nytænkning af demokratiet i retning af et mere kosmopolitisk demokrati.

Den slags tanker vil uden tvivl møde modstand fra nationalisterne og kommunitaristerne, der betragter det som urealistisk at skabe demokratisk ansvarlighed og legitimitet på højere niveauer end inden for rammen af suveræne nationalstater. Men spørgsmålet er så, om det nationale demokrati i længden kan holde til, at det ikke effektivt er i stand til at tage virkningsfulde beslutninger om de stadig flere grænseoverskridende udfordringer for økonomi, sikkerhed og miljø.

\section{Kosmopolitisk realpolitik}

Kolonihavetænkningen kommer let til kort i Europa såvel som på den globale arena. Ulrich Beck har skarpt kritiseret den metodologiske nationalisme og i stedet slået til lyd for en slags kosmopolitisk realpolitik, der ser hele kloden som et felt for global indenrigspolitik. Han har direkte sagt, at "det nationale nulsumssuverænitetsspil, der eksisterer i mange menneskers hoveder, har vist sig at være historisk set falsk: Gensidig afhængighed kan og må skabes og forstås som et plussumsspil, hvor alle involverede parter kan få magtgevinster."

Risikoen for kosmopolitanismen dette ambitiøse oplysningsprojekt 
udtrykt af Immanuel Kants arvtagere - er, at den i kampen om folks følelser og overbevisninger ikke rigtig kan konkurrere med den varme, følelsesfulde og mytedannende nationalisme. Måske kan den kun lykkes, hvis kosmopolitterne forstår af mobilisere og artikulere en ny form for patriotisme - et lidenskabeligt samfundsengagement - der bevidst styrer uden om den gamle nationalismes etniske, racistiske og kulturalistiske vildveje.

Et af de nok bedste forsøg på at formulere et sådant projekt er Jürgen Habermas' ide om i europæisk sammenhæng at samles om en ny forfatningspatriotisme: En ny patriotisme forstået som et engageret medborgerskab, hvor folk forenes i forsvaret for fælles politiske institutioner, de universelle liberal-demokratiske værdier og en solidarisk politik.

Det bliver ikke let at overvinde den gamle nationalismes historiske arv og begrebernes tyngde. Men det kosmopolitiske demokrati og den nye forfatningspatriotisme kan blive til realpolitik, når det går op for europæerne, at nationalismens territoriale tænkning igen og igen ender $\mathrm{i}$ afmægtighed og hjælpeløshed over for de store globale udfordringer.

Bjarke Møller er journalist ved Dagbladet Politiken. Han har i en årrekke skrevet om globaliseringen, og han er bl.a. forfatter til bogen 'I hadets have' om den baskiske nationalisme. 